\title{
Loss of toxicity by Pseudanabaena galeata in culture ${ }^{1}$
}

\author{
Angelica Nunes Garcia ${ }^{2,5}$, Fernando Pipole ${ }^{3}$, Luciana Castro da Cunha ${ }^{3}$, Fabiana Elias ${ }^{4}$, \\ Silvana Lima Górniak ${ }^{3}$, Célia Leite Sant'Anna ${ }^{2}$ and Luciana Retz de Carvalho²
}

Received: 6.7.2016; accepted: 18.04.2017

\begin{abstract}
Loss of toxicity by Pseudanabaena galeata in culture). Pseudanabaena galeata, a well-known toxin-producer, is commonly found in water supplies. In order to assess potential risks associated with oral exposure to this cyanobacterium, mouse toxicological studies were carried out with the monoespecific strain $P$. galeata CCIBt 3082, which has been kept in culture since 1996. In our studies, the acute oral lethal dose has been estimated to be $5,000 \mathrm{mg} \mathrm{kg}^{-1} \mathrm{bw}$ and, in the oral sub-chronic assays, the animals showed a decrease in weight and presented microscopic intestinal lesions, results that did not correspond to statements by other authors. In their studies, oral administration of the extract, whose acute lethal dose has been established to be $1,000 \mathrm{mg} \mathrm{kg}^{-1} \mathrm{bw}$, led to severe intoxication and promoted hepatic and renal lesions. Toxicity loss of this strain may be the result of reductive evolution that can occur in organisms that remain in static environments for long periods.
\end{abstract}

Keywords: adaptive process, changes in culture, cyanobacteria, toxicity loss

RESUMO - (Perda de toxicidade de Pseudanabaena galeata em cultura). Pseudanabaena galeata, produtora de toxina letal, é encontrada frequentemente em reservatórios de água para abastecimento. Para avaliar o potencial risco associado à exposição, por via oral, a esta cianobactéria, foram realizados estudos toxicológicos em camundongos com a cepa uniespecífica $P$. galeata CCIBt 3082, mantida em cultura desde 1996. Em nossos estudos, a dose oral letal aguda foi de $5.000 \mathrm{mg} \mathrm{kg}^{-1} \mathrm{pc} \mathrm{e}$ o teste oral subcrônico mostrou diminuição do peso e lesões microscópicas nos intestinos, resultados que contrastaram com os experimentos levados a efeito com esta cepa, em períodos anteriores. Nesses estudos, a administração oral do extrato causou severa intoxicação e lesões hepáticas e renais e a dose letal oral média foi de $1.000 \mathrm{mg} \mathrm{kg}^{-1} \mathrm{pc}$. A perda de toxicidade dessa cepa pode ser resultado de evolução redutiva, fenômeno que ocorre em organismos que permanecem em ambientes estáticos por longos períodos.

Palavras-chave: cianobactéria, mudanças em cultura, perda de toxicidade, processos adaptativos

\section{Introduction}

Pseudanabaena galeata is a toxic species which has cosmopolitan distribution and is a frequent component of the water supply reservoirs microflora in Brazil (Sant'Anna et al. 2007, Teneva et al. 2009).

To evaluate the risk posed by this harmful cyanobacteria to mammals, mouse toxicological studies were carried out on the P. galeata CCIBt 3082 strain, established as a monospecific lineage and kept in culture since 1996.

A first study by our research group, reported that the administration of a single $1.000 \mathrm{mg} \mathrm{kg}^{-1}$ body weight (bw) oral dose of $P$. galeata extract caused mice death over a period of 12 days; however, no changes were seen following intraperitoneal administration (Cunha et al. 2010).

These results are different from those described by Teneva et al. (2009), which were assigned to microcystins, anatoxin-a and saxitoxin contained in P. galeata extract administered intraperitoneally (i.p.) (Cunha et al. 2010, Pipole et al. 2010).

More detailed studies performed with a single dose of $P$. galeata $0.1 \mathrm{M}$ acetic acid extract $\left(1,000 \mathrm{mg} \times \mathrm{kg}^{-1}\right.$ bw, per os) showed that P.galeata toxic principle

1. Parte da dissertação de Mestrado da primeira Autora

2. Instituto de Botânica, Núcleo de Pesquisa em Ficologia, Av. Miguel Stéfano, 3.687, 04301-902 São Paulo, SP, Brasil

3. Universidade de São Paulo, Faculdade de Veterinária e Zootecnia, Departamento de Patologia, Av. Prof. Dr. Orlando Marques de Paiva, 87, 05508-270 São Paulo, SP, Brasil

4. Universidade Federal da Fronteira Sul, Faculdade de Medicina Veterinária, Setor de Gestão Educacional, Rua Edmundo Gaievisk, 1000, 85770-000 Realeza, PR, Brasil

5. Corresponding author: angelsgarcia@uol.com.br 
caused transient symptoms such as eyebrow ptosis, straub tail and pain. Hemorrhagic liver and lesions in the kidney were observed in the euthanized animals (Rangel et al. 2014).

All these findings, along with the fact that this strain did not present morphological changes throughout the period in which it was kept in culture, had driven us to continue the $P$. galeata study.

Notwithstanding, a restricted lifestyle such as laboratory conditions can lead to loss of accessory genes and consequently to morphological and/or biochemical changes (Otsuka et al. 2000, Schatz et al. 2005, Christiansen et al. 2008, Yoshida et al. 2008, Jacinavicius et al. 2016).

Morphological changes are easily perceivable so they are often recorded in cyanobacteria kept in culture where frequently the organisms lose their mucilaginous envelope and aerotopes, and change from colonies to isolated cells (Beard et al. 2002, Mlouka et al. 2004, Day et al. 2005, Zhang et al. 2007, Rios et al., 2016).

Biochemical changes ascribed to gene deletion events and detected as toxic metabolite loss were observed in free-living and cultured Microcystis strains as well as in microalgae maintained in culture conditions (Martins et al. 2004, Schatz et al. 2005, Christiansen et al. 2008). Likewise, these biochemical changes can also be noticed by the loss of the biological activity of an organism.

We hereby describe the loss of the toxicological activity of $P$. galeata CCIBt 3082, after a longterm culture maintenance, by performing acute and subchronic essays on cyanobacterial extract.

\section{Material and methods}

The organism - Pseudanabaena galeata CCIBt 3082 strain was collected from IAG Lake, at the Parque Estadual das Fontes do Ipiranga (PEFI), in São Paulo, on 11 November 1996. The isolation of a single individual was performed, in a flow chamber, by spread plate technique followed by the removal of the selected filament, with the aid of a capillary tube (Jacinavicius et al. 2013).

Thenceforward, this strain has been preserved under constant conditions: medium BG-11, temperature of $22 \pm 1{ }^{\circ} \mathrm{C}$, irradiance of $15-20 \mu \mathrm{mol} \mathrm{m} \mathrm{m}^{-2} \mathrm{~s}^{-1}$ and photoperiod of 14:10 light:dark, as part of the Cyanobacterial Culture Collection of the SP Institute of Botany (CCIBt).
Strain cultivation and extract obtention - The strain P. galeata CCIBt 3082 was grown in BG-11 medium under the same conditions described above, with a constant agitation speed of $70 \mathrm{rpm}$, until the culture reached the late exponential phase of growth (Azevedo $\&$ Sant'Anna 2003). The biomass was then frozen at $-20{ }^{\circ} \mathrm{C}$ and lyophilized. In all previous studies on this species (Cunha et al. 2010, Pipole et al. 2010, Rangel et al. 2014) the biomass was withdrawn from culture at this phase; at this stage of growth, the strain was toxic. To ensure repeatability, the same experimental procedure was used.

The lyophilized biomass was submitted to ultrasound assisted $(4 \times 30 \mathrm{sec}, 100 \mathrm{~W})$ extraction with $0.1 \mathrm{M}$ acetic acid, followed by centrifugation $(1,045 \times \mathrm{g}, 50 \mathrm{~min}, 4 \times)$. The supernatants were pooled and lyophilized (Harada et al. 1999, Pyo \& Shin 2002).

Biological studies - Animals - Swiss Webster male mice weighing between 19 and $22 \mathrm{~g}$ were used throughout these experiments. These animals were obtained from animal house of the Department of Pathology, Faculty of Veterinary Medicine and Animal Science, University of São Paulo - FMVZ/ USP. All protocols and procedures regarding to animal experiments in this study were approved and authorized by the Ethics Committee on Animal Use FMVZ/USP, Protocol 3012/2013. All efforts were made to minimize the number of animals used and their suffering.

The animals were housed in individual cages $(30 \times 20 \times 19 \mathrm{~cm})$ in a temperature and humidity controlled room $\left(21{ }^{\circ} \mathrm{C}-24{ }^{\circ} \mathrm{C}\right.$ and $65 \%-70 \%$ respectively), on an artificial $12 \mathrm{~h}$ light/dark cycle and free access to food and potable water.

Acute toxicity test (single dose), by intraperitoneal via - The acute toxicity tests were carried out according to the World Health Organization guidelines (Harada et al. 1999). A single intraperitoneal dose $[1,000$ $\mathrm{mg} \mathrm{kg}^{-1}$ body weight (bw)] of P. galeata lyophilized extract was administered to mice $(\mathrm{N}=3)$; Deionized water was used as vehicle and as well intraperitoneally administered to control-animals $(1 \mathrm{~mL})$.

The intoxication signs and survival time (when applicable) were recorded. After a 7-day observation period the animals were euthanized and necropsy was performed immediately after euthanasia.

Acute median lethal dose determination $\left(\mathrm{DL}_{50}\right)$, oral administration - This determination was carried out according to OECD - 425 (OECD 2008a) guidelines. 
The test started with the lowest dose which was first administered orally to a single animal. The survival or death of the animal have determined the administration of the same dose, or of a higher dose to another animal. The doses of $P$. galeata $0.1 \mathrm{M}$ acetic acid extract administered were $175,550,1,750,2,250$, $3,250,4,250$ e $5,000 \mathrm{mg} \mathrm{kg}^{-1} \mathrm{bw}$, all of them dissolved in drinking water.

Subchronic oral toxicity test (28-day period) - This assay was carried out following the OECD - 407 protocol (OECD 2008b). Five mice were used for each of 4 groups. The control-group received drinking water and the other three received 500, 1,000 and $1,500 \mathrm{mg} \mathrm{kg}^{-1}$ bw of P.galeata CCIBt 3082 extract dissolved in drinking water, for 28 days. Animals were daily observed throughout the period.

After extract administration, the animals were observed for a period of $3 \mathrm{~h}$ to verify the occurrence of intoxication signs such as limited mobility, skin and mucous membranes alterations, piloerection, sialorrhea, seizures, hyperexitability, abdominal constriction, stereotypic movements, tremors, diarrhea, lethargy and coma (Brito 1994).

Evaluation of weight gain and water and feed consumption - The mice were weighed before treatment to allow statistically homogeneous distribution of the animals. The intake of water and feed along with the animal weight were measured on alternate days, throughout the experimental period, data also used for estimating the dose required to treat the animals (OECD 2008b).

Evaluation of relative organ weights - At the end of each treatment, the animals were anesthetized with intraperitoneally administered ketamine and xylazine (5 and $50 \mathrm{mg} \mathrm{kg}^{-1} \mathrm{bw}$, repectively) and rapidly decapitated by guillotine. Directly after this procedure spleen, liver, kidneys, some parts of the intestine, thymus and central nervous system (CNS) were collected and weighed.

Histopathological studies - The collected organs and tissues were fixed in 10\% neutral buffered formalin, serially dehydrated in alcohol, diaphanized in a xylol solution and included in paraffin blocks which were cut on a microtome. The resulting slides were deparaffinized and stained with Hematoxylin and eosin according to the standard procedure (Cardiff et al. 2014). Then the slides were observed and photographed under optical microscope.
Statistical Analysis - The variance analysis (ANOVA) followed by Dunnett's test was used to detect significant differences among animal groups. The results were presented as mean with standard deviation, all statistical analysis were performed using GraphPad Instat v 5.01 software.

\section{Results}

Acute toxicity test (single dose), by intraperitoneal via - After intraperitoneal treatment with a dosage of $1,000 \mathrm{mg} \mathrm{kg}^{-1} \mathrm{bw}$, the animals showed signs of intoxication such as prostration and piloerection. Loose stools enveloped in mucus were observed as well.

The animals recovered approximately 4 hours after the extract was administered.

Congested liver was seen throughout necropsy on mice sacrificed after a 7-day observation period (figure 1).

Acute median lethal dose determination $\left(\mathrm{DL}_{50}\right)$, oral administration - Acute median lethal dose determined according to the OECD - 425 protocol was $5,000 \mathrm{mg} \mathrm{kg}^{-1}$ bw of lyophilized $0.1 \mathrm{M}$ acetic acid P.galeata extract (mice). Testing data are shown in table 1.

Intoxication signs of animals (tremors, prostation, and piloerection) which survived lower doses regressed $3 \mathrm{~h}$ post administration. Liver congestion was seen on the gross postmortem examination (figure 2).

Subchronic oral toxicity test (28-day period) - The small weight difference between control and treated animals was not statistically significant (table 2). The same occurred between differences in feed and water intake (table 3 and 4) (figure 3).

Relative weights of spleen, thymus, liver and kidneys are showed in table 5 . There was no significant

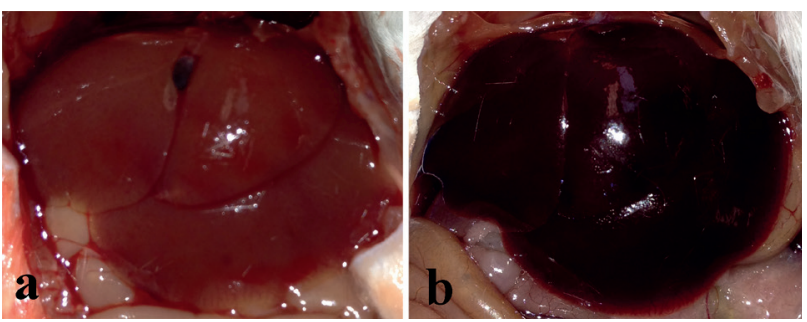

Figure 1. Image of control (a) and mouse liver (b) intraperitoneally treated with P.galeata CCIBt $30820.1 \mathrm{M}$ acetic acid extract as a single dosage of $1,000 \mathrm{mg} \mathrm{kg}^{-1} \mathrm{bw}$ b - Significant liver congestion. 
Table 1. Intoxication signs data compilation from orally administered $P$. galeata CCIBt 3082 extract to mice.

\begin{tabular}{|c|c|c|}
\hline $\begin{array}{l}\text { Dose } \\
\left(\mathrm{mg} \mathrm{kg}^{-1} \mathrm{bw}\right)\end{array}$ & Animal number & Intoxication signs \\
\hline 175 & 1 & Agitation \\
\hline 550 & 1 & Agitation \\
\hline 1,750 & 1 & No apparent changes \\
\hline 2,250 & 1 & Transient prostration \\
\hline 3,250 & 1 & Agitation and mild tremors \\
\hline 4,250 & 2 & Agitation, followed by prostration \\
\hline 5,000 & 3 & $\begin{array}{l}\text { Prostration, staggering gait and circling, rotation around their own axe, } \\
\text { tremors and muscle spasms. After two hours, lack of response to stimulus. } \\
\text { Purplish tail. Animal death occurred 5-15 h post extract administration }\end{array}$ \\
\hline
\end{tabular}

Table 2 Total weight gain evaluation (g) of mice orally administered with 500, 1,000 e 1,500 mg kg-1 doses of P. galeata CCIBt $30820.1 \mathrm{M}$ acetic acid extract, for 28 days.

\section{Weight gain}

(g)

\begin{tabular}{ccccc}
\hline & Control $^{\mathrm{a}}$ & $500 \mathrm{mg} \mathrm{kg}$ & $1.000 \mathrm{mg} \mathrm{kg}$ & $1.500 \mathrm{mg} \mathrm{kg}^{\mathrm{a}}$ \\
\hline Total & $10,22 \pm 2,37$ & $9,10 \pm 1,48$ & $7,26 \pm 1,56$ & $8,86 \pm 1,49$ \\
\hline
\end{tabular}

${ }^{\mathrm{a}} \mathrm{n}=5$ mice per group. Data are presented as mean \pm standard error. There was no significant difference $(\mathrm{p}<0.05)$ compared to control group (ANOVA, followed by Dunnett)

Table 3. Mean of daily and total feed intake (g) of control and groups orally treated with $500,1,000$ e $1,500 \mathrm{mg} \mathrm{kg}^{-1}$ of de P. galeata $0.1 \mathrm{M}$ acetic acid extract for 28 days.

\begin{tabular}{|c|c|c|c|c|}
\hline \multicolumn{5}{|c|}{$\begin{array}{c}\text { Intake (28 days) } \\
\text { (g) }\end{array}$} \\
\hline & Control $^{\mathrm{a}}$ & $500 \mathrm{mg} \mathrm{kg}^{\mathrm{a}}$ & $1,000 \mathrm{mg} \mathrm{kg}$ & $1,500 \mathrm{mg} \mathrm{kg}^{\mathrm{a}}$ \\
\hline Daily & $4,72 \pm 0,52$ & $4,61 \pm 0,39$ & $4,95 \pm 0,56$ & $4,45 \pm 0,53$ \\
\hline Total & $132,08 \pm 14,69$ & $128,98 \pm 10,87$ & $138,58 \pm 15,61$ & $124,57 \pm 14,79$ \\
\hline
\end{tabular}

${ }^{\mathrm{a}} \mathrm{n}=5$ mice per group. Data are presented as mean \pm standard error. There was no significant difference $(\mathrm{p}<0.05)$ compared to control group (ANOVA, followed by Dunnett).

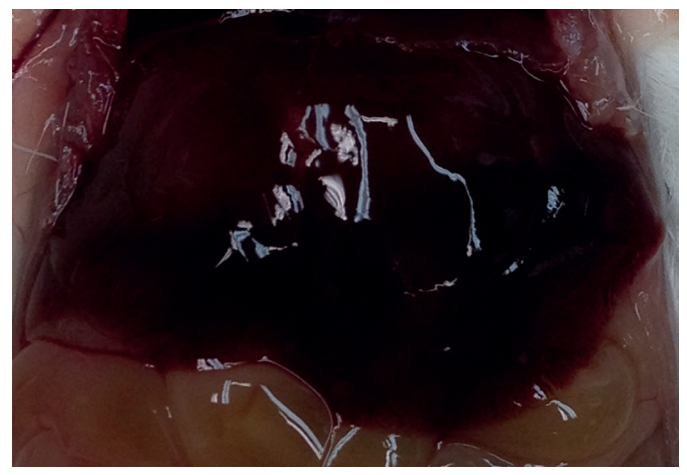

Figure 2. Image of liver from a mouse orally treated with a single dose $\left(5,000 \mathrm{mg} \mathrm{kg}^{-1}\right.$ b.w of P.galeata CCIBt $30820.1 \mathrm{M}$ acetic acid extract. Significant liver congestion. difference between organ weight values of control and treated groups (figure 4).

On microscopic examination, circulatory, degenerative and inflammatory changes were not found in brain, thymus, spleen, kidneys nor liver. However, in the histological examination of the intestine, a greater number of cystic dilations were found at the top of the villi due to dilation of lymphatic vessels. This may be attributed to a mild inflammatory process in the region (figure 5).

Bone marrow and spleen cellularities have not shown statistically difference between control and treated groups as well (tables 6 and 7) (figure 6). 
Table 4. Mean of daily and total water intake $(\mathrm{mL})$ of control and groups orally treated with $500,1,000 \mathrm{e} 1,500 \mathrm{mg} \mathrm{kg}^{-1} \mathrm{of}^{-}$ de $P$. galeata $0.1 \mathrm{M}$ acetic acid extract for 28 days.

\section{Intake (28 dias)}

$(\mathrm{mL})$

\begin{tabular}{|c|c|c|c|c|}
\hline & Control $^{\mathrm{a}}$ & $500 \mathrm{mg} \mathrm{kg}^{\mathrm{a}}$ & $1,000 \mathrm{mg} \mathrm{kg}^{\mathrm{a}}$ & $1,500 \mathrm{mg} \mathrm{kg}^{\mathrm{a}}$ \\
\hline Daily & $8,97 \pm 1,02$ & $10,01 \pm 1,03$ & $10,50 \pm 1,20$ & $10,35 \pm 1,60$ \\
\hline Total & $251,14 \pm 28,44$ & $280,30 \pm 28,89$ & $293,96 \pm 33,97$ & $289,68 \pm 44,76$ \\
\hline
\end{tabular}

${ }^{a} \mathrm{n}=5$ mice per group. Data are presented as mean \pm standard error. There was no significant difference $(\mathrm{p}<0.05)$ compared to control group (ANOVA, followed by Dunnett).

Table 5 Relative weights of spleen, thymus, liver and kidneys (g per $100 \mathrm{~g}$ of body weight) of control and orally treated groups with $500,1,000$ and $1,500 \mathrm{mg} \mathrm{kg}^{-1}$ bw of $P$. galeata $0.1 \mathrm{M}$ acetic acid extract, for 28 days.

\begin{tabular}{|c|c|c|c|c|}
\hline \multicolumn{5}{|c|}{$\begin{array}{l}\text { Organ relative weights } \\
\text { (g } 100 \mathrm{~g}^{-1} \text { body weight) }\end{array}$} \\
\hline Organ & Control $^{\mathrm{a}}$ & $500 \mathrm{mg} \mathrm{kg}^{\mathrm{a}}$ & $1.000 \mathrm{mg} \mathrm{kg}{ }^{\mathrm{a}}$ & $1.500 \mathrm{mg} \mathrm{kg}{ }^{\mathrm{a}}$ \\
\hline Spleen & $0,23 \pm 0,03$ & $0,33 \pm 0,09$ & $0,30 \pm 0,06$ & $0,28 \pm 0,04$ \\
\hline Thymus & $0,11 \pm 0,02$ & $0,13 \pm 0,04$ & $0,12 \pm 0,03$ & $0,14 \pm 0,04$ \\
\hline Liver & $4,93 \pm 0,12$ & $4,76 \pm 0,60$ & $4,78 \pm 0,62$ & $4,95 \pm 0,59$ \\
\hline Kidneys & $0,80 \pm 0,11$ & $0,81 \pm 0,07$ & $0,83 \pm 0,06$ & $0,86 \pm 0,06$ \\
\hline
\end{tabular}

${ }^{a} \mathrm{n}=5$ mice per group. Data are presented as mean \pm standard error. There was no significant difference $(\mathrm{p}<0.05)$ compared to control group (ANOVA, followed by Dunnett).

Table 6. Spleen cellularity of control and orally treated groups with 500, 1,000 and 1,500 mg kg-1 bw of P. galeata $0.1 \mathrm{M}$ acetic acid extract, for 28 days.

\begin{tabular}{cccc}
\hline \multicolumn{4}{c}{ Spleen cellularity } \\
$\left(\right.$ Cell $\left.\times 10^{6}\right)$ \\
\hline Control $^{\mathrm{a}}$ & $500 \mathrm{mg} \mathrm{kg}$ & $1.000 \mathrm{mg} \mathrm{kg}$ & $1.500 \mathrm{mg} \mathrm{kg}^{\mathrm{a}}$ \\
$4,10 \pm 1,57$ & $5,16 \pm 2,75$ & $5,86 \pm 1,19$ & $3,43 \pm 1,08$ \\
\hline
\end{tabular}

${ }^{a} \mathrm{n}=5$ animals per group. Data are presented as mean \pm standard error. There was no significant difference $(\mathrm{p}<0.05)$ compared to control group (ANOVA, followed by Dunnett).

Table 7. Bone marrow cellularity of control and orally treated groups with $500,1,000$ and $1,500 \mathrm{mg} \mathrm{kg}^{-1} \mathrm{bw}$ of $P$. galeata $0.1 \mathrm{M}$ acetic acid extract, for 28 days.

\begin{tabular}{cccc}
\hline \multicolumn{4}{c}{ Bone marrow cellularity } \\
$\left(\right.$ Cell $\left.\times 10^{6}\right)$ & \\
\hline Control $^{\mathrm{a}}$ & $500 \mathrm{mg} \mathrm{kg}^{\mathrm{a}}$ & $1.000 \mathrm{mg} \mathrm{kg}^{\mathrm{a}}$ & $1.500 \mathrm{mg} \mathrm{kg}^{\mathrm{a}}$ \\
$2,95 \pm 1,19$ & $3,13 \pm 1,11$ & $4,26 \pm 2,14$ & $3,98 \pm 0,79$ \\
\hline
\end{tabular}

${ }^{\mathrm{a}} \mathrm{n}=5$ animals per group. Data are presented as mean \pm standard error. There was no significant difference $(\mathrm{p}<0,05)$ compared to control group (ANOVA, followed by Dunnett). 

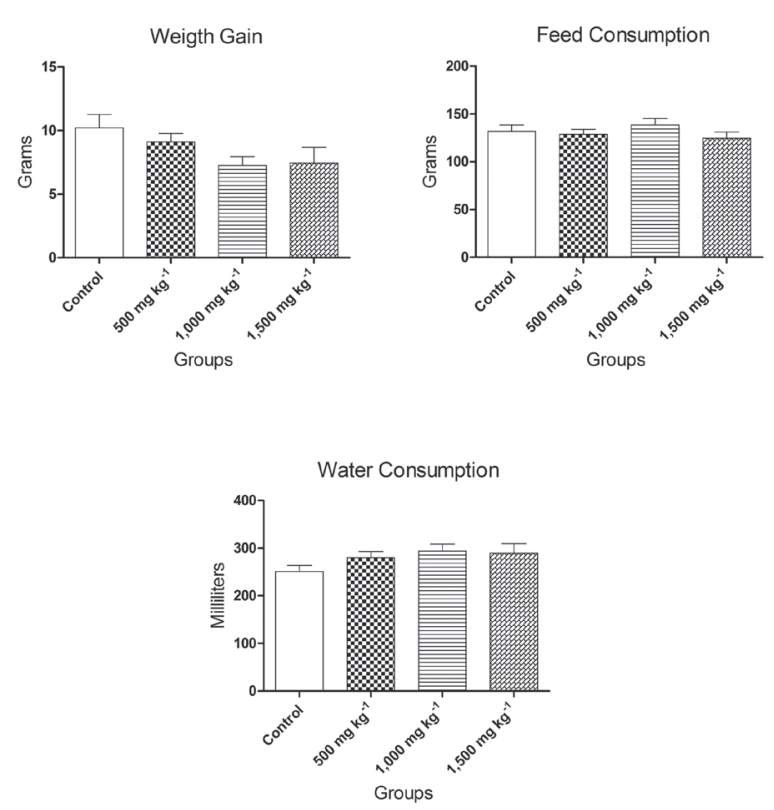

Figure 3. Total weight gain $(\mathrm{g})$, total feed $(\mathrm{g})$ and water intake $(\mathrm{mL})$ of animals orally treated with different doses of P. galeata $0.1 \mathrm{M}$ acetic acid extract, for 28 days. Data are presented as mean \pm standard error.
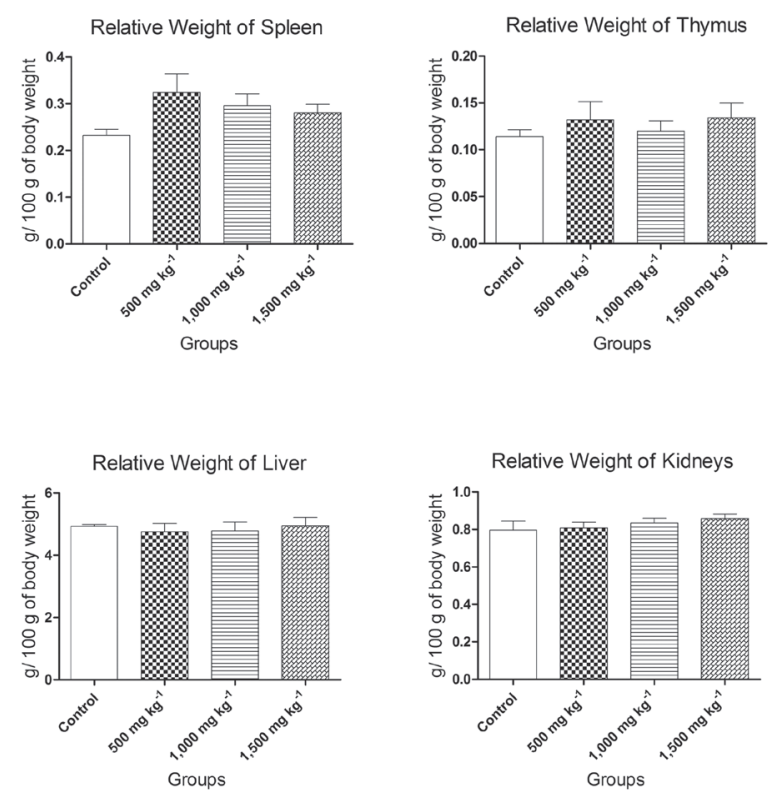

Figure 4. Relative weights of spleen, thymus, liver and kidneys (g/ $100 \mathrm{~g}$ of body weight) of control and groups orally treated with $500,1,000$ and $1,500 \mathrm{mg} \mathrm{kg}^{-1}$ bw of $P$. galeata $0.1 \mathrm{M}$ acetic acid extract, for 28 days. Data are presented as mean \pm standard error.

\section{Discussion}

P. galeata was toxic to mice orally treated with a single dose of $5,000 \mathrm{mg} \mathrm{kg}^{-1} \mathrm{bw}$, what falls into category 5 of the Globally Harmonized System of Classification and Labeling of Chemicals (Kadam 2011). This group includes compounds with relatively low toxicity, but which may have detrimental health effects on humans exposed to them for long periods of time (Winder et al. 2005).

P. galeata CCIBt 3082 strain was kept in culture since 1996 and - in 2010- was subjected to in vivo studies to determine their potential toxic effects to mammals (Cunha et al. 2010, Pipole et al. 2010). Then, the oral administration to mice of a single $1,000 \mathrm{mg} \mathrm{kg}^{-1}$ bw dose of the cyanobacterial extract led animals to death within 12 days. Hepatic necrosis and renal congestion were observed in the postmortem studies coupled with numerous blood clots all along the intestine. Histological analyses revealed moderate congestion in the kidney, spleen, and intestine. Furthermore, there were moderate to severe congestion and zonal vacuolar degeneration of the liver.

In a further study carried out in 2012 (Rangel et al. 2014), the $P$. galeata CCIBt 3082 extract, at the
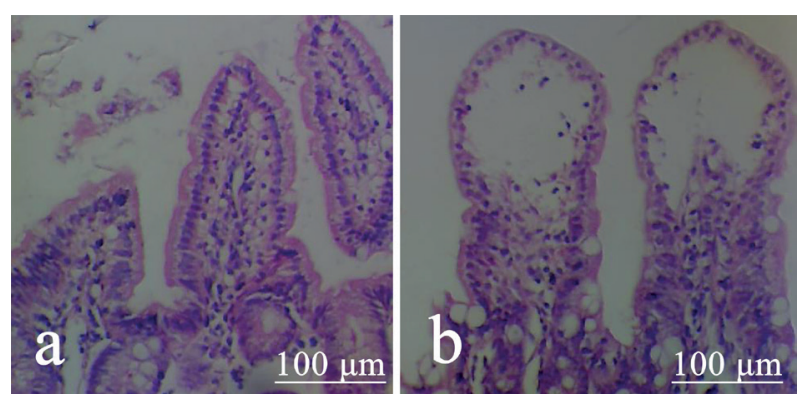

Figure 5. Photomicrographs of a control (a) and a treated animal (b) intestine. The last one received orally a dose of $P$. galeata $0.1 \mathrm{M}$ acetic acid extract $\left(1,500 \mathrm{mg} \mathrm{kg}^{-1} \mathrm{bw}\right)$ for 28 days. A greater number of cystic dilations were observed at the top of the villi due to dilatation of lymphatic vessels. Hematoxylin and eosin stain, $1,000 \times$ magnification $(a$ and $b)$.
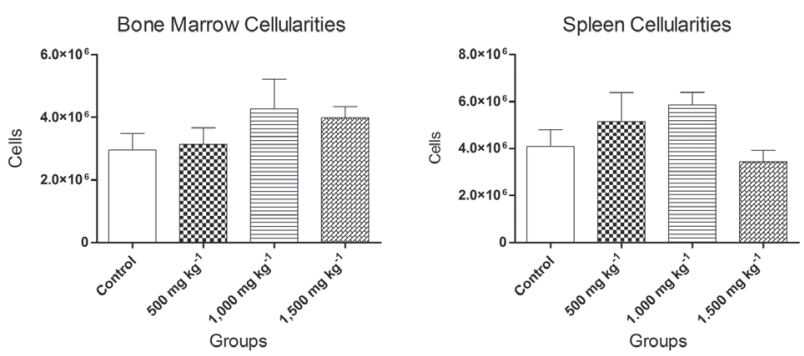

Figure 6. Bone marrow and spleen cellularities of control and treated animals. The last ones received orally different doses of $P$. galeata $0.1 \mathrm{M}$ acetic acid extract, for 28 days. Data are presented as mean \pm standard error. 
same dosage of $1,000 \mathrm{mg} \mathrm{kg}^{-1} \mathrm{bw}$, no longer caused the death of the animals, but induced intoxication signs, such as eyebrow ptosis, straub tail, and pain. The animals were sacrificed after an eight-day observation period and on gross examination, they presented hemorrhage in the liver. The histological study showed necrosis, hyperemia and parenchymal liver disorder. Furthermore, enlargement and cellular hypertrophy of convoluted tubules of kidneys were observed; the lungs were not affected at all. In this second toxicological study, the $P$. galeata extract neither caused animal death nor the onset of blood clots in intestines, but still retained some toxic activity.

The differences among the data published by Cunha et al. (2010), Pipole et al. (2010), Rangel et al. (2014) and those observed in our study are remarkable. The toxicity of $P$. galeata principle has decreased over time since the level of the single oral dose, which is capable of causing animal death, has increased from $1,000 \mathrm{mg} \mathrm{kg}^{-1} \mathrm{bw}$ (Pipole et al. 2010) to $5,000 \mathrm{mg} \mathrm{kg}^{-1}$ bw (acute median lethal dose as per our study). Unlike those previous works, animal weight loss was not observed.

Besides such inequalities, in these preceding works (Cunha et al. 2010, Pipole et al. 2010) macroscopic and microscopic lesions were found in the animal's intestines and in all three studies (Cunha et al. 2010, Pipole et al. 2010, Rangel et al. 2014) microscopic lesions were observed in the kidneys, which have not been observed in our study. In the present work, different microscopic lesions were found in the animal's intestines after a 28-day period test (dilation of intestinal lymphatic vessels).

Cunha et al. (2010) and Pipole et al. (2010) have not reported the intoxication signs presented by treated animals; those described by Rangel et al. (2014) (eyebrow ptosis, straub tail, and pain) can be assigned to central nervous system reactions, as the ones observed in this study (tremors, piloerection and prostation) (Brito 1994).

These differences corroborate the hypothesis of biochemical change occurrence (activity loss or reduction) in $P$. galeata CCIBt 3082 strain, event already described for other cyanobacteria species kept for long periods under static conditions (Day et al. 2005, Zhang et al. 2007) and (Masel et al. 2007).

\section{Acknowledgments}

The authors wish to thank Coordenação de Aperfeiçoamento de Pessoal de Nível Superior (CAPES, Brazil) for the scholarship awarded to the first author.

\section{Literature cited}

Azevedo, M.T.P. \& Sant'Anna, C.L. 2003. Sphaerocavum brasiliense, a new plankitic genus and species of cyanobacteria from reservoirs of Sao Paulo state, Brazil. Algological studies 109: 79-92.

Beard, S.J., Handley, B.A. \& Walsby, A.E. 2002. Spontaneous mutations in gas vesicle genes of Planktothrix spp. affect gas vesicle production and critical pressure. FEMS Microbiology letteres 215: 189-195.

Briand, E., Escoffier, N., Straub, C., Sabart, M., Quiblier, C. \& Humbert, J.F. 2009. Spatiotemporal changes in the genetic diversity of a bloom-forming Microcystis aeruginosa (cyanobacteria) population. The ISME Journal 3: 419-429.

Brito, A.S. 1994. Manual de ensaios toxicologicos in vivo. UNICAMP, São Paulo.

Cardiff, R.D., Miller, C.H. \& Munn, R.J. 2014. Manual hematoxylin and eosin staining of mouse tissue sections. Cold Spring Harbor Protocols.

Christiansen, G., Molitor, C., Philmus, B. \& Kurmayer, R. 2008. Nontoxic strains of Cyanobacteria are the result of major gene deletion events induced by a transposable element. Molecular Biology and Evolution 25: 1695-1704.

Cunha, L.C., Pipole, F., Arjonilla-de-Mattos, L., Rangel, M., Sant'Anna, C.L., Garcia, A. \& Carvalho, L.R. 2010. Efeitos tóxicos do extrato de Pseudanabaena galeata administrados via oral e via intraperitoneal. Anais da Semana Científica Eurico Malucelli 4: 159-160.

Day, J.G., Benson, E.E., Harding, K., Knowles, B., Idowu, M., Bremner, D., Santos, L., Santos, F., Lorenz, M., Lukesova, A.A., Elster, J., Lukavsky, J., Herdman, M., Rippka, R. \& Hall, T. 2005. Cryopreservation and conservation of microalgae: The development of a Pan-European Scientific and Biotechnological resource (The COBRA Project). CryoLetters 26: 231-238.

Frangeul, L., Quillardet, P., Castets, A.M., Humbert, J.F., Matthijs, H.C.P., Cortez, D., Tolonen, A., Zhang, C.C., Gribaldo, S., Kehr, J.C., Zilliges, Y., Ziemert, N., Becker, S., Talla, E., Latifi, A., Billault, A., Lepelletier, A., Dittmann, E., Bouchier, C. \& Marsac, N.T. 2008. Highly plastic genome of Microcystis aeruginosa PCC 7806, a ubiquitous toxic freshwater cyanobacterium. BMC Genomic 9: 274-293.

Gao, Z.M., Wang, Y., Tian, R.M., Wong, Y.H., Batang, Z.B., Al-Suwailem, A.M., Bajic, V.A. \& Qian, P.Y. 2014. Symbiotic adaptation drives genome streamlining of the Cyanobacterial sponge symbiont "Candidatus Synechococcus spongiarum”. mBio 5(2)e 00079-14.

Harada, K.I., Kondo, F. \& Lawton, L. 1999. Laboratory analysis of cyanotoxins. In: I. Chorus, J. Bartram (eds.). Toxic cyanobacteria in water. A guide to their public health consequences, monitoring and management. $\mathrm{E}$ \& FN SPON, New York, pp 369-405. 
Hilton, J.A., Foster, R.A., Tripp, H.J., Carter, B.J., Zehr, J.P. \& Villareal, T.A. 2013. Genomic deletions disrupt nitrogen metabolism pathways of a cyanobacterial diatom symbiont. Nature Communications 4: 1767.

Jacinavicius, F.R., Carneiro, R.L., Sant'Anna, C.L., Rigonato, J. \& Carvalho, L.R. 2016. Phenotypic plasticity and negative allelopathy in Microcystis strains. Ann microbiology 66: 1265-1276.

Jacinavicius, F.R., Gama-Jr, W.A., Azevedo, M.T.P. \& Sant'Anna, C.L. 2013. Manual para cultivo de cianobactérias, Instituto de Botânica, São Paulo.

Kadam, S. 2010. Globally Harmonized System of Classification and Labeling of Chemicals. Chemical Engineering World 45: 46-49.

Kurmayer, R., Christiansen, G., Fastner, J. \& Börner, T. 2004. Abundance of active and inactive microcystin genotypes in populations of the toxic cyanobacterium Planktothrix spp. Environmental Microbiology 6: 831-841.

Kurmayer, R., Christiansen, G., Gumpenberger, M. \& Fastner, J. 2005. Genetic identification of microcystin ecotypes in toxic cyanobacteria of the genus Planktothrix. Microbiology 151: 1525-1533.

Lee, M.C. \& Marx, C.J. 2012. Repeated, selection-driven genome reduction of accessory genes in experimental populations. PLoS Genetics 8: e10002651.

Martins, C.A., Kulis, D., Franca, S. \& Anderson, D.M. 2004. The loss of PSP toxin production in a formerly toxic Alexandrium lusitanicum clone. Toxicon 43: 195-205.

Masel, J., King, O.D. \& Maughan, H. 2007. The loss of adaptive plasticity during long periods of environmental stasis. The American Naturalist 169: 38-46.

Mlouka, A., Comte, K., Castets, A.M., Bouchier, C. \& Marsac, N.T. 2004. The gas vesicle gene cluster from Microcystis aeruginosa and DNA rearrangements that lead to loss of cell buoyancy. Journal of Bacteriology 186: 2355-2365.

Ochman, H. \& Moran, N.A. 2001. Genes lost and genes found: Evolution of bacterial pathogenesis and symbiosis. Science 292: 1096-1098.

Oecd (Organisation for Economic Co-operation and Development). 2008a. Guidelines for the testing of chemicals: Acute Oral Toxicity - Up-and-DownProcedure (UDP) item 425.

Oecd (Organisation for Economic Co-operation and Development). 2008b. Guidelines for the testing of chemicals: Repeated Dose 28-Day Oral Toxicity Study In Rodents item 407.

Otsuka, S., Suda, S., Li, R., Matsumoto, S. \& Watanabe, M.M. 2000. Morphological variability of colonies of Microcystis morphospecies in culture. Journal of General and Appllied Microbiology 46: 39-50.
Paul, S., Dutta, A., Bag, S.K., Das, S. \& Dutta, C. 2010. Distinct, ecotype-specific genome and proteome signatures in the marine cyanobacteria Prochlorococcus. BMC Genomics 11: 103-118.

Pipole, F., Arjonilla-de-Mattos, L.F., Garcia, A.N., Cunha, L.C., Rangel, M., Sant'Anna, C.L. \& Carvalho, L.R. 2010. Avaliação dos possíveis efeitos tóxicos do extrato de Pseudanabaena galeata administrados via oral e intraperitoneal. Anais do XIII Congresso Brasileiro de Ficologia, Paraty, pp. 1-75.

Pyo, D. \& Shin, H. 2002. Extraction and analysis of microcystins RR and LR in cyanobacteria using a cyano cartridge. Journal of Biochemical and Biophysical Methods 51: 103-109.

Ran, L., Larsson, J., Vigil-Stenman, T., Nylander, J.A.A., Ininbergs, K., Zheng, W.W., Lapidus, A., Lowry, S., Haselkorn, R. \& Bergman, B. 2010. Genome erosion in a nitrogen-fixing vertically transmitted endosymbiotic multicellular cyanobacterium. PLOS ONE 5: e11486.

Rangel, M., Martins, J.C.G., Garcia, A.N., Conserva, G.A.A., Costa-Neves, A., Sant'Anna, C.L. \& Carvalho, L.R. 2014. Analysis of the toxicity 1 and histopathology induced by the oral administration of Pseudanabaena galeata and Geitlerinema splendidum (Cyanobacteria) extracts to mice. Marine Drugs 12: 508-524.

Sant'Anna, C.L., Melcher, S.S., Carvalho, M.C., Gemelgo, M.P. \& Azevedo, M.T.P. 2007. Plantic cyanobacteria from Alto Tietê Basin, Brazil. Revista Brasileira de Botânica 30: 1-17.

Schatz, D., Keren, Y., Hadas, O., Carmeli, S., Sukenik, A. \& Kaplan, A. 2005. Ecological implications of the emergence of non-toxic subcultures from toxic Microcystis strains. Environmental Microbiology 7: 798-805.

Sun, Z. \& Blanchard, J.L. 2014. Strong genome-wide selection early in the evolution of Prochlorococcus resulted in a reduced genome through the loss of a large number of small effect genes. PLOS ONE 9: e88837.

Thacker, R.W. 2005. Impacts of shading on spongecyanobacteria symbioses: a comparison between hostspecific and generalist associations. Integrative and Comparative Biology 45: 369-376.

Winder, C., Azzi, R. \& Wagner, D. 2005. The development of the globally harmonized system (GHS) classification and labelling of hazardous chemicals. J Hazard Mater 2000, 125: 29-44.

Yoshida, M., Yoshida, T., Satomi, M., Takashima, Y., Hosoda, N. \& Hiroishi, S. 2008. Intra-specific phenotypic and genotypic variation in toxic cyanobacterial Mycrocystis strains. Journal of Applied Microbiology 105: 407-415.

Zhang, M., Kong, F., Tan, X., Yang, Z., Cao, H. \& Xing, P. 2007. Biochemical, morphological, and genetic variations in Microcystis aeruginosa due to colony disaggregation. World Journal of Microbiology and Biotechnology 23: 663-670. 